\title{
Access to mental health care in El Salvador: a case study of progress toward decentralization
}

\author{
Samuel V. Nickels, ${ }^{1}$ Mariely Campos Tomasino, ${ }^{2}$ Nelson A. Flamenco Arvaiza, ${ }^{2}$ \\ and Cynthia A. Hunter ${ }^{3}$
}

Suggested citation

Nickels SV, Campos Tomasino M, Flamenco Arvaiza N, Hunter CA. Access to mental health care in El Salvador: a case study of progress toward decentralization. Rev Panam Salud Publica. 2018;42:e172. https://doi.org/10.26633/RPSP.2018.172

ABSTRACT Objective. To assess the need for decentralization of psychiatric services in El Salvador, based on country-specific evidence, and to generate baseline measures the government and researchers could use to monitor and measure future progress toward decentralization.

Methods. Observations were made and psychiatric outpatients and their families/caregivers $(n=453)$ surveyed with a cross-sectional instrument at the National Psychiatric Hospital (Hospital Nacional General y de Psiquiatría "Dr. José Molina Martinez") in the capital city of San Salvador. Findings were compared with national census data to determine barriers to psychiatric care in a largely centralized system. The following data were collected: department of origin, travel time to hospital, time in hospital, costs, and qualitative comments about accessing services. Descriptive statistics and regression were used to assess the data. Government reports on all psychiatric outpatient consultations provided nationwide in $2015(\mathrm{n}=61$ 010) at 10 regional hospitals were also reviewed and compared to population data to determine the proportion of the population of each hospital service area (department or group of departments) that received a psychiatric outpatient consultation.

Results. Households from the half of the country (7 out of 14 departments) farthest away from the National Psychiatric Hospital (42\% of the general population) spent twice as much time and three times as much money to access the hospital's psychiatric outpatient services, resulting in severe hardship on both patients and families/caregivers.

Conclusions. This report estimates that $45 \%$ of those with mental health needs in the seven departments farthest away from the National Psychiatric Hospital departments are still not accessing services compared to the seven departments nearest the hospital. The results of this study support the World Health Organization's call for governments to fully implement community-based mental health systems. This is the first study to assess progress toward decentralization of psychiatric services in El Salvador.

Keywords Community mental health services, utilization, organization \& administration; decentralization; equity in access to health services, mental health care services; El Salvador.

\footnotetext{
Center for Health and Human Development, Harrisonburg, VA, United States of America. Send correspondence to: Samuel Nickels, samuelnickels@yahoo.com
}

\footnotetext{
Asociacion de Capacitacion e Investigacion para la Salud Mental, San Salvador, El Salvador.

Department of Social Work, College of Health and Behavioral Studies, James Madison University, Harrisonburg, Virginia, United States of America.
}

Mental and substance use disorders are the leading cause of years lived with disability (YLDs), with youth ages 10-29 years suffering the highest 
proportion of disability-adjusted life years (DALYs) (1). In Latin America and the Caribbean (LAC), mental disorders represent $24.5 \%$ of the burden of disease, far more than any other group of illnesses (2), yet the majority of governments in Central America spend only 1\% of their national health budgets on mental health. In El Salvador, $92 \%$ of the budget for mental health goes to cover the costs of the National Psychiatric Hospital (Hospital Nacional General y de Psiquiatría "Dr. José Molina Martínez") (3).

Studies have demonstrated the importance and benefits of decentralization of mental health services. These include patients receiving outpatient care at a rate three times higher than in areas with centralized services (4), reduced suicide rates (5), lower costs (6), and reduced use of jails as holding cells for people with mental conditions (7). In India, a study of decentralization showed that nearly $80 \%$ of patients with mental illness for a year or longer coming to a new urban treatment facility had no past psychiatric treatment or only irregular treatment. Two of the six reasons given by patients for not seeking treatment previously were distance and cost (8).

Since the Declaration of Caracas in 1990, advocates have been calling for the decentralization of mental health services across the LAC region (9). However, continued, recent calls indicate that progress is limited (10-13).

The pace of change to communitybased mental health systems has been very slow in LAC countries, with the exception of Brazil, Chile, and Panama, as well as Belize (14-17). All four countries reduced the number of mental hospital beds by a significant amount $(62 \%$ over a 10-year period in Brazil, Chile, and Panama, and 55\% in Belize over a similar time period), in contrast to other countries in the region, who reduced the number of beds by only $24 \%$. This reform was facilitated in the first three countries by increasing the percentage of public mental health expenditures allocated to general hospitals, outpatient facilities, and community services-68\% in Brazil, $88 \%$ in Chile, and 56\% in Panama; Belize opted to decentralize its mental health care program by training more primary care psychiatric nurses in each health district (14).

In El Salvador, some progress has been made. For example, by the end of 2015, psychiatrists had been placed in 11 out of 30 of the country's public hospitals, and primary care physicians were being trained to implement the World Health Organization (WHO) Mental Health Gap Action Programme (mhGAP), which provides a set of manuals on mental health treatment and referral protocols to help doctors provide mental health treatment at the community level. ${ }^{4}$ Yet the government's commitment to increasing access to mental health services remains unclear, given that as of December 2016 the Ministry of Health $(\mathrm{MoH})$ had trained only 365 or $5.7 \%$ of public sector doctors in the mhGAP protocols, and the program has come to a standstill. ${ }^{5}$ To the best of the authors' knowledge no previous assessment of decentralization of mental health services in El Salvador has been published.

The objective of this study was to assess the need for decentralization of psychiatric services in El Salvador, based on country-specific evidence, and to generate baseline measures the government and researchers could use to monitor and measure future progress toward decentralization.

\section{MATERIALS AND METHODS}

Data collection for this case study consisted of three parts: 1) a cross-sectional survey $^{6}$ of 453 psychiatric patients and their family members/caregivers seeking mental health care services at the outpatient clinic of the National Psychiatric Hospital in San Salvador, including both quantitative and qualitative questions; 2) observations of care-seeking by the same sample group; and 3) a review of $\mathrm{MoH}$ reports on outpatient psychiatric consultations at 10 regional hospitals (18) and comparison with population census data. This approach was used to triangulate findings and to collect a broader range of information, including qualitative data that would help explain the impact on families of the time and distance data collected in the quantitative questions.

Survey subjects were interviewed over a period of three months, from November 2015 to January 2016. Participants came from all 14 departments of El Salvador.

\footnotetext{
A. Carranza, personal communication, October 2015.

5 K. Juarez, personal communication, 7 December 2016.

6 The STROBE (Strengthening The Reporting of OBservational Studies in Epidemiology) checklist for cross-sectional studies was used as a guide to help ensure adequate coverage of content.
}

Data were collected at the household level, using a brief-screening method (surveys of 2-3 minutes), so no personal or demographic information was collected. The researchers talked with as many households as possible, at the clinic. Household members included users of mental health services, family caregivers, and any other person(s) who had a primary and long-term role in supporting the person with the mental condition. Persons who were unwilling or unable to respond to the questions were excluded from the study and totaled less than 5\% of those screened.

During the three months of the study, on the majority of days the clinic was open, the team of one to three researchers arrived just prior to the 6:30 am, 10:30 am, and 12:30 pm time slots to speak with people waiting for their appointments. An announcement was made in the waiting room describing the study, and the survey; the researchers, and their professional affiliations; and how the researchers would conduct the interviews. The researchers spoke to each household privately, beginning the interview by asking if they agreed to answer a few questions, and letting them know that they could refuse, without repercussions, and that their participation was anonymous. Due to contextual factors and to ensure anonymity of subjects, an oral approach, rather than signed informed consent, was used.

The survey consisted of a few structured and semi-structured questions. ${ }^{7}$ Some of the households (40) provided additional commentary about their experiences, voluntarily. The methodology for assessing these qualitative data is described below. Variables of interest included department of origin; travel time to hospital; time in hospital; total cost and breakdown of costs (transportation, food, lodging); type of transportation (foot, bus, taxi); number of people who came together (household group); and qualitative comments about experiences accessing care. Descriptive statistics and regression were used to analyze/summarize the quantitative data. Distance was the predictor variable, while time, cost, and number of households by department were the outcome variables.

The list of survey questions is available from the
corresponding author (SVN). 
TABLE 1. Sample illustrative comments from households (patients/families/ caregivers) surveyed in mental health case study, by theme, about challenges in accessing care at the National Psychiatric Hospital, San Salvador, El Salvador, November 2015-January 2016

\begin{tabular}{|c|c|}
\hline Theme $\left(\%{ }^{a}\right)$ & Sample illustrative comments \\
\hline \multirow[t]{2}{*}{ Human rights abuse $(5 \%)$} & $\begin{array}{l}\text { "When I'm at the hospital I have to leave my loved one locked in the } \\
\text { house." }\end{array}$ \\
\hline & "While I go to the appointment for the day, I have to leave him tied up." \\
\hline \multirow{2}{*}{$\begin{array}{l}\text { Physical hardship } \\
(5 \%)\end{array}$} & "I spent the night in the hospital, sleeping on the ground." \\
\hline & "I spent the night sleeping here in this seat." \\
\hline \multirow[t]{2}{*}{ Financial burden-hunger (30\%) } & $\begin{array}{l}\text { "I didn't eat because I don't have money. I'll stand it until I get back to the } \\
\text { house." }\end{array}$ \\
\hline & "We came in a taxi, but now there's not enough money left for us to eat." \\
\hline \multirow[t]{2}{*}{$\begin{array}{l}\text { Financial burden-transportation } \\
(20 \%)\end{array}$} & $\begin{array}{l}\text { "We paid } \$ 70 \text { to come in a taxi from Usulután because our ill loved one } \\
\text { cannot handle the trip on a public bus." }\end{array}$ \\
\hline & $\begin{array}{l}\text { "We pay a neighbor to take us in his car. We pay } \$ 120 \text { to him, and food is } \\
\text { about } \$ 20 \text { for all of us." }\end{array}$ \\
\hline $\begin{array}{l}\text { Financial burden-no bus money } \\
(7.5 \%)\end{array}$ & $\begin{array}{l}\text { "I came on foot because I don't have bus fare ( } 25 \text { cents)." } \\
\text { "I walked. I have no money for the bus." }\end{array}$ \\
\hline $\begin{array}{l}\text { Financial burden-spent money } \\
\text { on lodging }(32.5 \%)\end{array}$ & $\begin{array}{l}\text { "We come from the interior. We have to spend the night in San Salvador in } \\
\text { a guest house." } \\
\text { "There isn't time to get here for our morning appointment, so we have to } \\
\text { come the day before." }\end{array}$ \\
\hline
\end{tabular}

Source: Prepared by the authors based on the study results.

a Proportion of all comments from the $25 \%$ of the total survey sample (40 of 163 households) that provided feedback about their experience seeking care. As the study did not explicitly ask everyone in the sample for comments, the authors believe that far more than $25 \%$ of care-seekers experience these challenges. Further, it is unknown how many are not coming to the hospital as a result of these barriers.

For the qualitative analysis, responses to questions as well as unsolicited comments were recorded for each of the 163 households screened. Using simple content analysis, comments were assessed by hand by the first two authors (SVN and MCT) and categorized by consensus into common themes (listed, with sample comments for each one, in Table 1). The authors then reviewed the final themes and representative comments for face validity and comparison with the conclusions drawn from the quantitative data. A group of eight psychiatrists from the National Psychiatric Hospital later reviewed the findings and had no disagreements with either the qualitative or quantitative data and findings.

Data on the number of psychiatric outpatient visits available at all 30 hospitals in the country were collected from $\mathrm{MoH}$ reports available on the ministry website (18). Only 10 of the 30 hospitals reported psychiatric consultations for 2015 ( $n=61$ 010, with more than half reported by the National Psychiatric Hospital in San Salvador). The research team, with support from consultants, developed calculations to compare the number of consultations by department with population census data by department to estimate the percentage of persons by department that should be receiving mental health services if there were an even distribution of services across the country. ${ }^{8}$

The study was carried out in accordance with ethical protocols of human subject research and approved by both the institutional review board at James Madison University (protocol \#15-0463) and the National Psychiatric Hospital ethics committee.

\section{RESULTS}

As the psychiatric patients and their families/caregivers were highly unreliable in identifying the current diagnosis, hospital statistics were used as a proxy for estimating sample proportions of illness type. For 2015, the top diagnoses treated by psychiatrists in the outpatient clinic of the National Psychiatric Hospital were epilepsy (5 287 persons), depressive episode (3 590), organic mental disorder (3 525), paranoid schizophrenia (2 745), organic affective disorder (1 959), and mixed anxiety and depression (1 546). Men were seen for organic mental disorder and schizophrenia

\footnotetext{
The two-page explanation of the calculation used is available from the corresponding author (SVN).
}

more than women, while women were seen far more frequently for mood disorder complaints. Treatment consisted of minimal and irregular psychoeducation by a nurse, followed by a meeting with a psychiatrist for the patient and family member/caregiver and provision of medication prescriptions. A social worker or psychologist was sometimes available to discuss various topics with patients and families, including substance abuse and other issues.

\section{Travel time and cost}

It took families an average of more than 2 hours to travel to the hospital (mean: 2.15 hours, margin of error of 6 minutes; median: 2.00 hours; standard deviation (SD): 2.01 hours, range: 0.0812.00 hours; $n=448$ ), or more than 4 hours roundtrip (Figure 1). ${ }^{9}$ Those who lived nearby walked 5 or 10 minutes, but others traveled for 4 hours or more. Doubling the average one-way 2-hour figure, the roundtrip was more than 4 hours. When time waiting in the hospital is included, the average trip was more than 8 hours. As a result, families often lose a day of income for each trip. Some families spent the night near the hospital so they could catch an early bus to the hospital. A few slept in chairs or on the hospital floor for the night before their early morning appointments.

Caregivers who live far away could not always bring their loved one who was ill, usually because the patient had physical or emotional limitations that prevented him/her using public transportation over long distances, and the family could not afford to take a taxi such a distance. Some family caregivers commented that while they went to the hospital to keep the medical appointment, they had to leave their patient tied up or locked in the house.

Household expenses were primarily related to transportation, meals, and sometimes overnight accommodation. The average expenses per household were just under US\$13, but some households spent much more, with the four households that spent the most spending

\footnotetext{
Sample sizes and margins of error are reported because all families were not asked all questions, so missing data were not estimated. Margins of error assume an annual population of patients at the National Psychiatric Hospital during the last two years of 35000 , a confidence level of $95 \%$, and a response distribution of $50 \%$.
} 
FIGURE 1. Time required (hours) for psychiatric patients/families/caretakers to travel to outpatient consultations at the National Psychiatric Hospital, San Salvador, El Salvador, November 2015-January 2016

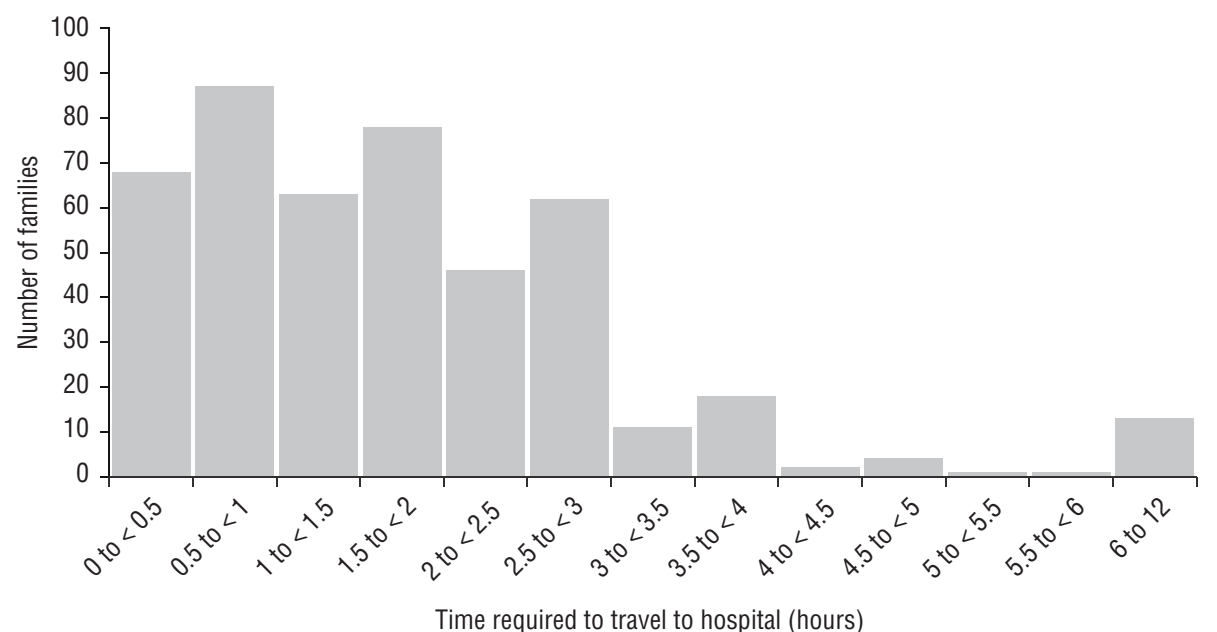

Source: Prepared by the authors based on the study results.

between US\$ 100 and US\$ 210 (mean: US\$ 12.57, margin of error US\$ 0.62; median: US\$ 9.00; SD: US\$ 17.36, range: US\$ 0-\$210; $n=450$ ) (Figure 2)..$^{10}$ These amounts are significant compared to the minimum wage in the country, which averages US\$ 5.33 per day.

This study did not ask or include information about purchases of medications from private pharmacies when the prescribed medications were not available free from the hospital. The cost of medications in El Salvador is a complex issue beyond the scope of this report. For example, while a psychiatrist may be available in a rural regional hospital for a consultation, medications must often be obtained from the National Psychiatric Hospital, meaning an additional trip.

\section{Time in the hospital}

The mean time for being at the hospital is almost 4 hours (mean: 3.73 hours, margin of error 17 minutes; SD: 1.27, range: $1-9$ hours; $n=163$ ) (Figure 3 ). Based on observations and interviews, it is clear that families have to wait in several long lines in the outpatient clinic, including 1) the registration line, to sign in; 2) the line for the psychiatrists; and 3) the pharmacy line. The authors observed

\footnotetext{
10 These data do not include costs for one person from Honduras who spent US\$ 70 and one Salvadoran who lived in Costa Rica and spent US\$ 335. It is not unusual for people in Central American countries to cross borders to access mental health services to overcome a variety of barriers.
}

80 or more people in the pharmacy line on multiple occasions.

In 2016, the authors of this report surveyed the National Psychiatric Hospital pharmacy and seven public regional hospital pharmacies by phone to determine whether the medications that doctors and psychiatrists are allowed to prescribe were available. Results indicated that second-generation psychiatric medications were not often available; first-generation medications were available more frequently, but no medications were consistently available all year long. On average, according to hospital pharmacists, requested medications were available about half the time. If the hospital pharmacy does not have a medication, the family is told to call back regularly to see if it is available. However, hospital pharmacies sometimes do not answer the phone, despite repeated calls. As a result, families are often forced to make repeated trips to hospital pharmacies in search of needed medications.

\section{Number of people by department}

El Salvador has 14 departments comprising a population of 6.3 million. The largest percentage of households in the sample for this study (34.6\%) came from the department of San Salvador, where the National Psychiatric Hospital is located. The four departments around San Salvador had the next largest number of households seeking care (about 10\% each). The smallest number of people came from the departments farthest from San Salvador-to the East, Morazán $(1.3 \%)$, and to the West, Ahuachapán $(1.6 \%)$.

\section{Comparison of time and cost by department}

Travel time and expenses for families were compared by two sets of department of origin: the seven departments nearest to the National Psychiatric Hospital and the seven farthest away from it. Families from the second group had to travel twice the time to access outpatient services compared to families from the first group (3.76 hours versus 1.85 hours each way). Families from the second group also spent almost three times more than the first group (US\$ 27.48 versus US\$ 9.83) (Table 2). Some people only spent a little, even though they traveled quite a distance, because after paying money for the buses they had no money left for food or lodging. These patients and families ate little to nothing at all while seeking/waiting for care. For them, it is a great sacrifice to access treatment.

To see if there was a significant correlation between distance (the independent variable) and 1) time, 2) cost, and 3) number of families, by department, who came to the National Psychiatric Hospital for outpatient services, regression analysis was used. The analysis showed strong effect sizes for all three pairs of variables: distance and time to arrive at the hospital $\left(P<0.001 ; \mathrm{R}^{2}: 0.29 ; \mathrm{R}: 0.54 ; \mathrm{F}(1,446)\right.$ : 180.341); distance and costs $(P<0.001$; $\mathrm{R}^{2}$ : 0.28; R: 0.53; $\left.\mathrm{F}(1,448): 176.110\right)$; and distance and number of families, by department, who came to the National Psychiatric Hospital for outpatient services $\left(P=0.022 ; \mathrm{R}^{2}\right.$ : $0.36 ; \mathrm{R}: 0.60 ; \mathrm{F}(1,12)$ : 6.880).

Table 1 lists qualitative themes and sample comments that reflect the impact of time and cost on family burden. The most common theme was the burden of spending money on lodging, mentioned by $32.5 \%$ of the survey participants who made unsolicited comments (40 out of 163 households, or $25 \%$ ). This was followed by the burden of not having enough money for both transportation and food, leaving the survey participant(s) hungry $(30 \%)$. Next was the burden of spending on transportation $(20 \%)$, followed by those who had no money for even public bus rides and so had to walk 
FIGURE 2. Money spent (US\$) by psychiatric patients/families/caretakers to travel to outpatient consultations at the National Psychiatric Hospital, San Salvador, El Salvador, November 2015-January 2016

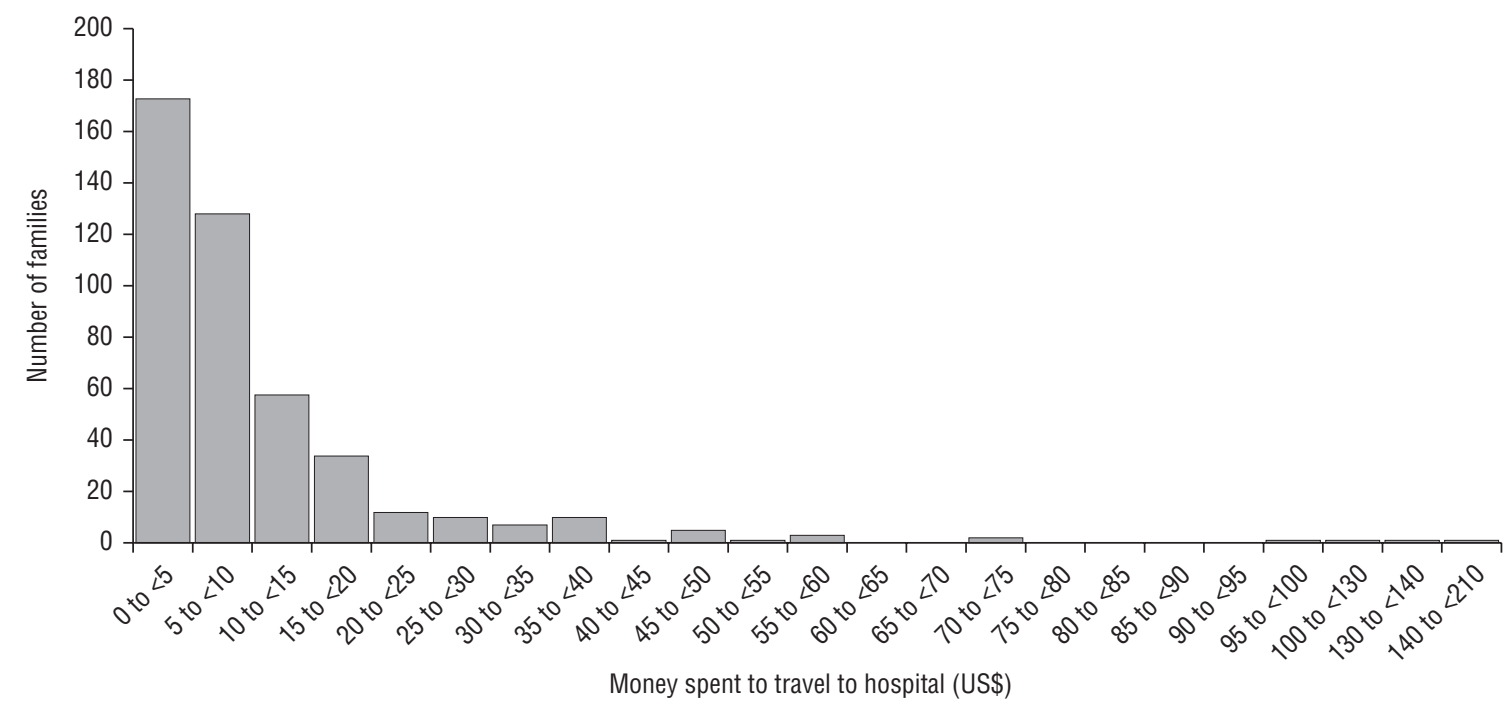

Note: El Salvador uses U.S. dollars as its currency.

Source: Prepared by the authors based on the study results.

FIGURE 3. Time spent (hours) by psychiatric patients/families/caretakers for outpatient consultations at the National Psychiatric Hospital, San Salvador, El Salvador, November 2015-January 2016

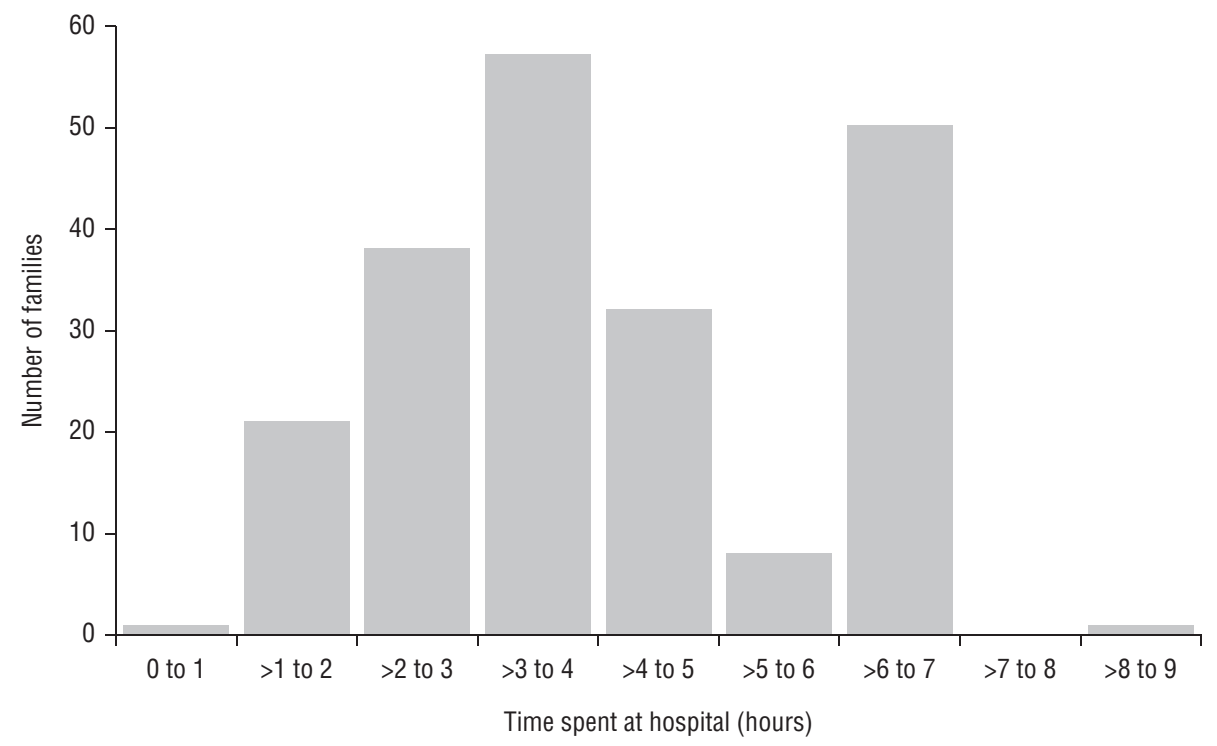

Note: Does not include time spent at hospital overnight waiting for morning outpatient appointment. Source: Prepared by the authors based on the study results.

to the hospital $(7.5 \%)$, then physical hardship $(5 \%)$, and resulting human rights abuses (5\%).

\section{Analysis of $\mathrm{MoH}$ data on psychiatric outpatient visits}

Because the survey data did not include information from other hospitals where patients were receiving psychiatric outpatient services, and to take into account that the $\mathrm{MoH}$ had begun to decentralize some psychiatric outpatient consultations, the authors reviewed documents on the $\mathrm{MoH}$ website to obtain the number of psychiatric outpatient consultations in 2015 provided at all 30 hospitals in El Salvador and compared these data with census data by department. A total of 10 hospitals reported psychiatric outpatient consultation data, $60 \%$ of which came from the seven departments nearest to the National Psychiatric Hospital.

In the seven departments nearest to the National Psychiatric Hospital, five general hospitals reported offering psychiatric outpatient consultations. Two of these hospitals were in the capital city of San Salvador, relatively close to the National Psychiatric Hospital. In the seven departments farthest from the National Psychiatric Hospital, four hospitals reported offering psychiatric outpatient consultations (Table 2). The second-to-last column of Table 2 shows what percentage each department (or group of departments that share the same hospital(s) where psychiatric consultations are provided) reported above or below what would be expected if services were decentralized based on the respective proportion of the general population. The department group that included San Salvador was the only one that reported a greater number of consultations (44.4\% higher) than what would be expected based on its population. All other departments reported a lower proportion of consultations $(-14.9 \%$ to $-52.7 \%)$ than would be expected based on their share of the total population. The calculation used was a simple equation based on the population and share of consultations compared across departments. 
TABLE 2. Proportion (\%) of all psychiatric outpatient consultations provided nationwide compared with proportion (\%) of population, by groups of departments/states served by 10 regional hospitals, ${ }^{a}$ EI Salvador, 2015

\begin{tabular}{|c|c|c|c|c|c|c|}
\hline \multirow[t]{2}{*}{$\begin{array}{l}\text { Regional groups of } \\
\text { departments/states }\end{array}$} & \multicolumn{2}{|c|}{$\begin{array}{l}\text { Share of all psychiatric } \\
\text { outpatient consultations } \\
\text { provided nationwide } \\
\quad(n=61010)\end{array}$} & \multirow[t]{2}{*}{ Population ${ }^{b}$} & \multirow[t]{2}{*}{$\begin{array}{c}\text { Share }(\%) \text { of } \\
\text { national population }\end{array}$} & \multirow{2}{*}{$\begin{array}{c}\text { Share }(\%) \text { of psychiatric } \\
\text { outpatient consultations } \\
\text { versus share }(\%) \text { of } \\
\text { population }(\%+/-)^{c}\end{array}$} & \multirow{2}{*}{$\begin{array}{c}\text { Proportion of population } \\
\text { that received a } \\
\text { psychiatric outpatient } \\
\text { consultation }\end{array}$} \\
\hline & No. & $\%$ & & & & \\
\hline $\begin{array}{l}\text { 1. San Salvador, Cuscatlán, } \\
\text { La Paz, Cabañas, San Vicente }\end{array}$ & 37264 & 61.1 & 2661102 & 42.3 & +44.4 & 1.40 \\
\hline 2. Chalatenango & 1602 & 2.6 & 204808 & 3.3 & -21.2 & 0.78 \\
\hline 3. La Libertad & 4482 & 7.4 & 747662 & 11.9 & -37.8 & 0.60 \\
\hline 4. Sonsonate & 3840 & 6.3 & 463739 & 7.4 & -14.9 & 0.83 \\
\hline 5. Santa Ana, Ahuachapán ${ }^{d}$ & 6513 & 10.7 & 905487 & 14.4 & -25.7 & 0.72 \\
\hline 6. Usulután ${ }^{d}$ & 2971 & 4.9 & 366040 & 5.8 & -15.5 & 0.81 \\
\hline $\begin{array}{l}\text { 7. San Miguel, } \\
\text { La Unión, Morazánd }\end{array}$ & 4338 & 7.1 & 941582 & 15 & -52.7 & 0.46 \\
\hline Total & 61010 & 100.1 & 6290420 & 100.1 & & \\
\hline \multicolumn{7}{|c|}{$\begin{array}{l}\text { Source: Prepared by the authors based on Ministry of Health reports for } 2015 \text { on psychiatric outpatient consultations } \\
\text { nationwide (18) and census data. }\end{array}$} \\
\hline
\end{tabular}

Using information from the MoH reports, and population data, the authors estimated that $45 \%$ of the population in the seven departments farthest away from the National Psychiatric Hospital lack access to psychiatric services, despite efforts to decentralize consultations at the end of 2015. This translates into 14450 families without access. ${ }^{11}$

\section{DISCUSSION}

This study of decentralization of mental health services in El Salvador supports the concerns of LAC mental health leaders and researchers that progress toward community mental health services has been slow and is far from being achieved. Through both quantitative and qualitative data, the study adds evidence to the research demonstrating that there are significant time, cost, and emotional burdens on households when they have to travel to centralized services for mental health care. For example, this study estimates that $45 \%$ of people in need of mental health services are not accessing those services in the half of the country

\footnotetext{
11 A two-page explanation of the calculations used for this report is available from the corresponding author (SVN).
}

farthest from the National Psychiatric Hospital, possibly due to barriers of distance, time, and cost.

The qualitative comments indicated that people suffer a great deal from the challenges and obstacles inherent in a mental health system organized around a centralized psychiatric hospital for an entire country. Families have to make difficult choices, selecting a strategy from multiple bad options to obtain treatment, such as giving up daily income to attend the appointment. In El Salvador it is often a family caregiver or friend who goes to the appointment because the person with mental health problems often can not endure the travel due to physical, age, or emotional limitations, or the family simply does not have enough money. Families and users make difficult choices to travel long distances for treatment, including going without food or sleeping in chairs overnight at the hospital.

This report provides baseline measures that government and researchers could use to assess future progress toward decentralization of mental health services. These include the number of outpatient consultations provided outside the National Psychiatric Hospital, the number of hospitals providing psychiatric outpatient consultations, the number of health personnel trained in mhGAP, the distance traveled and costs incurred by households to access treatment, waiting times, and qualitative impacts.

To the best of the authors' knowledge, this type of study has not been carried out before in Central America. While recognizing that analysis of census and health care use ("consultation") data has limitations, this methodology is easy to implement and appears to be effective in determining a potential percentage of the population without access to mental health services. Although the data came from self-reports, the sample was sufficiently large, the response distribution curves of the raw data were normal, and the face value and consistency of responses was high. Taken together these indicate a high level of validity.

Generalizability of results is limited because the survey portion of the study sampled only one hospital. Still, the socioeconomic conditions found in $\mathrm{El}$ Salvador are similar to many other lowand middle-income countries, so the authors believe the conclusions are likely applicable to similar countries. In addition, quantitative studies from Norway (4), Finland (5), Spain (6), Canada (7), 
India (8), and Kenya (19) support the conclusions provided here. Further studies at the country level could strengthen the urgent call by WHO for decentralization of mental health services.

\section{Limitations}

Due to the brief-screening nature of the data collection method used in this survey, no demographic, medical, or household composition data were collected, which limited the scope of the study results. Other limitations included 1) missing data, which led to different sample sizes for different survey questions, and 2) the lack of good-quality epidemiologic data by department, which resulted in the authors' reliance on census and consultation data.

\section{Conclusions}

This study of decentralization of mental health services in El Salvador adds evidence to the broader literature on LAC countries that expresses concern about the slow and uneven progress toward community-based services in the region. A large percentage of households in the seven departments farthest from the National Psychiatric Hospital in El Salvador appear to be unable to access services. Burdens are significant and onerous for households to access to care. The authors offer baseline measures that government and researchers could use to assess future progress toward decentralization of mental health services.

\section{Recommendations}

The authors recommend that the Ministry of Health in El Salvador 1) use the data reviewed in this study as baseline measures to help monitor progress toward decentralization of mental health services, and 2) urgently implement a full decentralization process to reduce the burden of time and cost for those seeking care and to increase access to medications. Other recommendations include more extensive and rigorous research, including, 1) a national-level mental health epidemiology study to generate the very important yet still undetermined "needs" measure required to capture the impact of barriers such as stigma, denial, noncompliance, long waiting lines, and poverty that are not addressed in the census and consultation data used in this study, and 2) a more rigorous study capturing the influences of distance, time, and cost of travel to all main hospitals in the country that provide mental health services, as well as other barriers to care, to assess and strengthen this study's findings, which could further support the call for decentralization.

Acknowledgments. The authors express their heartfelt thanks to the following people: the administration, staff, and psychiatrists of the National Psychiatric Hospital in El Salvador (Hospital Nacional General y de Psiquiatría "Dr. José Molina Martinez"), for their endless support and feedback on the study's findings; Anne Stewart and Robin Anderson, for their review of this article and helpful

\section{REFERENCES}

1. Whiteford HA, Degenhardt L, Rehm J, Baxter AJ, Ferrari AJ, Erskine HE, et al. Global burden of disease attributable to mental and substance use disorders: findings from the Global Burden of Disease Study 2010. Lancet. 2013;382(9904):157586. doi: 10.1016/S0140-6736(13)61611-6.

2. World Health Organization. The global burden of disease: 2004 update. Geneva: WHO; 2008. Available from: http:// www.who.int/healthinfo/global_burden_disease /2004_report_update / en/

3. World Health Organization. IESM-OMS informe sobre los sistemas de salud mental en Nicaragua, El Salvador, Guatemala. Geneva: WHO; 2006. Available from: http:/ / www.who.int/mental_health / Nicaragua_ElSalvador_Guatemala_ WHO-AIMS_Report2.pdf
4. Myklebust LH, Olstad R, Bjorkekkmo S, Eisemann M, Wynn R, Sorgaard K. Impact on continuity of care of decentralized versus partly centralized mental health care in Northern Norway. Int J Integr Care. 2011;11(4):e142.

5. Pirkola S, Sohlman B, Heilä H, Wahlbeck K. Reductions in postdischarge suicide after deinstitutionalization and decentralization: a nationwide register study in Finland. Psychiatr Serv. 2007;58(2):221-6.

6. Salvador-Carulla L, Haro JM, Cabasés J, Madoz V, Sacristán JA, Vázquez-Barquero JL. Service utilization and costs of first-onset schizophrenia in two widely differing health service areas in North-East Spain. Acta Psychiatr Scand. 1999;100(5):335-43.

7. Smith CA, Wright D, Day S. Distancing the mad: Jarvis's Law and the spatial distribution of admissions to the Hamilton discussions; researchers, clinicians, family caregivers, persons with lived experience, and guest Ministry of Health officials who attended the 2016 annual meeting of the Regional Network for Mental Health (Red Regional de Salud Mental) in Costa Rica and provided feedback on this case study and its findings; Morgan Hennessey, Madison Carpenter, Annie Lin, and Maria Sokoloff, students of the James Madison University (JMU) Honors College, for assistance with figures and tables, references, map work, formatting, and innumerable other details; Lucy Mendez, Hugo Realegeño, Adriana Orellana, Jakob Waltner, and Susana Araujo, students at the University of El Salvador, for assistance in screening families at the National Psychiatric Hospital outpatient clinic; Raul Duran, Executive Director of the Asociación de Capacitación e Investigación para la Salud Mental (ACISAM), and ACISAM staff, for their support and financial management of the study; and JMU advisors Margaret Sloan and Karen Ford (School of Strategic Leadership Studies), and Kelly Foelber and Kristen Smith (Center for Assessment \& Research Studies), for research advice.

\section{Conflict of interests. None declared.}

Disclaimer. Authors hold sole responsibility for the views expressed in the manuscript, which may not necessarily reflect the opinion or policy of the RPSP/ PAJPH or the Pan American Health Organization (PAHO).
Lunatic Asylum in Canada, 1876-1902. Soc Sci Med. 2007;64(11):2362-77.

8. Waraich BK, Raj L, Chavan BS, Badhan R, Panda SN. Decentralisation of mental health services under DMHP. Indian J Psychiatry. 2003;45(3):161-5.

9. Pan American Health Organization. Declaración de Caracas. Washington: PAHO; 1990. Available from: https:// www.oas.org/dil/esp/Declaracion_de_ Caracas.pdf

10. Pan American Health Organization. Principios de Brasilia. Washington: PAHO; 2005. Available from: http://www1. paho.org/hq/dmdocuments / 2008/ PRINCIPIOS_dE_BRASILIA.pdf

11. Pan American Health Organization. Consenso de Brasilia. Washington: PAHO; 2013. Available from: https:// www.paho.org/hq/dmdocuments/2014/ 
BRASILIA-CONSENSUS-2013span. pdf?ua $=1$

12. World Health Organization. Mental health action plan: 2013-2020. Geneva: WHO; 2013. Available from: http://www. who.int/mental_health/publications / action_plan/en/

13. Kestel D. Regional advances in mental health since Caracas Declaration: Regional Atlas - 2014. Presentation at the Regional Conference on Mental Health "Achievements and challenges 25 years after the Caracas Declaration," Santiago, Chile, 2015. Available from: https: / / www. paho.org/hq/dmdocuments/2015/kestel-advances-mental-region.pdf

14. Minoletti A, Galea S, Susser E. Community mental health services in Latin America for people with severe mental disorders. Public Health Rev. 2012;34(2).

15. ArmijoJ,BoydY,HerreraJ.Reestructuración en la atención psiquiátrica: una experiencia innovadora en Panamá. Cuad Psiquiatr Comunitaria. 2009:9(2):147-53.

16. Gonçalves RW, Vieira FS, Delgado PG. Mental health policy in Brazil: federal expenditure evolution between 2001 and 2009. Rev Saude Publica. 2012;46(1):51-8. Epub 2011 December 20. doi: 10.1590/ S0034-89102011005000085.

17. Gómez Ch M. Avances en salud mental en Chile, a 25 años de la Declaración de Caracas. Presentation at the Regional Conference on Mental Health "Achievements and challenges 25 years after the Caracas Declaration," Santiago, Chile, 2015. Available from: https://www. paho.org/hq/dmdocuments/2015/ gomez-sepulveda-advances-mentachile.pdf

18. Ministry of Health (SV). Hospitales y Direcciones Regionales (35) [Internet]. San Salvador: MS; 2016. Available from: https:// www.transparencia.gob.sv/categories / 6 http:/ / publica.gobiernoabierto.gob.sv / institutions/hospital-nacional-general-yde-psiquiatria-dr-jose-molina-martinez/ information_standards/plan-operativoannual. Accessed on 15 October 2016.

19. Lund C, Waruguru M, Kingori J, KippenWood S, Breuer E, Mannarath S, et al. Outcomes of the mental health and development model in rural Kenya: a 2-year prospective cohort intervention study. Int Health. 2013;5(1):43-50. Available from: doi: 10.1093/inthealth/ ihs037.

Manuscript submitted 11 April 2018. Revised version accepted for publication on 6 June 2018.
RESUMEN

\section{Acceso a la atención de salud mental en El Salvador: un estudio de caso de progreso hacia la descentralización}

Palabras clave
Objetivo. Evaluar la necesidad de la descentralización de los servicios psiquiátricos en El Salvador con base en la evidencia específica del país y generar medidas de referencia que podrían ser utilizadas por el gobierno y los investigadores para monitorear y medir el progreso futuro hacia la descentralización.

Métodos. Se realizaron observaciones, y se encuestaron pacientes psiquiátricos ambulatorios y sus familiares/cuidadores $(n=453)$ con un instrumento de corte transversal en el Hospital Nacional Psiquiátrico (Hospital Nacional General y de Psiquiatría "Dr. José Molina Martínez") en la capital, San Salvador. Los hallazgos se compararon con los datos del censo nacional para determinar las barreras en el acceso a la atención psiquiátrica en un sistema en gran medida centralizado. Se recopilaron los siguientes datos: departamento de origen, tiempo de viaje al hospital, tiempo en el hospital, costos y comentarios cualitativos sobre el acceso a los servicios. Se usaron estadísticas descriptivas y regresión para evaluar los datos. También se revisaron informes gubernamentales sobre todas las consultas psiquiátricas ambulatorias proporcionados a nivel nacional en 2015 ( $n=61$ 010) en 10 hospitales regionales, y estos se compararon con datos poblacionales para determinar la proporción de la población de cada área de servicio hospitalario (departamento o grupo de departamentos) que efectuó una consulta psiquiátrica ambulatoria.

Resultados. Los hogares de la mitad del país (7 de los 14 departamentos) más alejados del Hospital Psiquiátrico Nacional (42\% de la población general) gastaron el doble de tiempo y tres veces más dinero para acceder a los servicios psiquiátricos ambulatorios del hospital, lo que resultó en dificultades económicas severas tanto para los pacientes como para sus familias/cuidadores.

Conclusiones. Este informe estimó que el $45 \%$ de las personas con necesidades de salud mental en los 7 departamentos más alejados del Hospital Nacional Psiquiátrico aún no tienen acceso a los servicios en comparación con los 7 departamentos más cercanos al hospital. Los resultados de este estudio respaldan el llamado de la Organización Mundial de la Salud para que los gobiernos implementen por completo sistemas de salud mental basados en la comunidad. Este es el primer estudio en evaluar el progreso hacia la descentralización de los servicios psiquiátricos en El Salvador.

Servicios comunitarios de salud mental, utilización, organización y administración; descentralización; equidad en el acceso a los servicios de salud; servicios de salud mental; El Salvador. 
RESUMO Objetivo. Avaliar a necessidade de descentralização dos serviços psiquiátricos em El Salvador com base em provas específicas do país e gerar medições de referência que poderiam ser usados pelo governo e pesquisadores para monitorar e medir o progresso futuro no sentido da descentralização.

Acesso à saúde mental em El Salvador: um estudo de caso sobre o progresso em direção à descentralização

Métodos. Observações foram feitas, e foram pesquisados pacientes psiquiátricos ambulatoriais e suas famílias/cuidadores $(n=453)$ com uma ferramentas de seção transversal no Hospital Psiquiátrico Nacional (National Hospital Geral e Psiquiatria "Dr. Jose Molina Martinez") na capital, São Salvador. Os resultados foram comparados com dados do censo nacional para determinar as barreiras ao acesso à assistência psiquiátrica em um sistema amplamente centralizado. Os seguintes dados foram coletados: departamento de origem, tempo de deslocamento para o hospital, tempo no hospital, custos e comentários qualitativos sobre o acesso aos serviços. Para avaliar os dados foram utilizadas estatística descritiva e regressão. Também foram analisados relatórios do governo sobre todas as consultas psiquiátricas ambulatoriais a nível nacional em 2015 ( $n=61$ 010) em 10 hospitais regionais, e comparados com os dados da população para determinar a proporção da população de cada área de serviço hospitalar (departamento ou grupo de departamentos) que recebeu uma consulta psiquiátrica para pacientes ambulatoriais.

Resultados. As pessoas da metade do país (7 dos 14 departamentos) mais afastada do Hospital Psiquiátrico Nacional (42\% da população geral) gastaram o dobro do tempo e três vezes mais dinheiro para acessar os serviços psiquiátricos ambulatoriais do hospital, o que resultou em privação severa para pacientes e familiares/cuidadores. Conclusões. Este relatório estimou que $45 \%$ das pessoas com necessidades de saúde mental nos 7 departamentos mais distantes do Hospital Psiquiátrico Nacional ainda não têm acesso aos serviços em comparação com os 7 departamentos mais próximos do hospital. Os resultados deste estudo apoiam o apelo da Organização Mundial de Saúde para que os governos implementem totalmente os sistemas de saúde mental baseados na comunidade. Este é o primeiro estudo a avaliar o progresso em direção à descentralização dos serviços psiquiátricos em El Salvador.

Palavras-chave Serviços comunitários de saúde mental, utilização, organização \& administração; descentralização; equidade no acesso aos serviços de saúde; serviços de saúde mental; El Salvador. 